\title{
15. CALCAREOUS NANNOFOSSIL BIOSTRATIGRAPHY, DEEP SEA DRILLING PROJECT LEG 85, EASTERN EQUATORIAL PACIFIC ${ }^{1}$
}

\author{
Stefan Gartner and Jinder Chow, Texas A\&M University ${ }^{2}$
}

\begin{abstract}
Pelagic sediments recovered during Leg 85 span the uppermost Eocene to Pleistocene interval in a series of fairly continuous sections. The calcareous nannofossils are normally not very well preserved in the cores from this leg; coccoliths, discoasters, and other morphologic types have been corroded and overgrown by secondary calcite. Poor preservation in some cases precludes a sharp and precise biostratigraphy at the subzonal level, although remarkably, most zones can be clearly identified. Middle Miocene markers are the most consistently troublesome, and it is suggested that Coronocyclus nitescens be introduced as an additional useful marker in this interval.
\end{abstract}

\section{INTRODUCTION}

During Leg 85, tropical deep-water pelagic sediments were cored in the equatorial Pacific. Four sites (572 to 575) in particular were cored extensively, and multiple holes were drilled at each site (Fig. 1). The sediment at each of these sites consists principally of pelagic, biogenic constituents, both calcareous and siliceous. In total, 217 samples from the four sites (two holes from each site) were used in biostratigraphic analysis. This chapter presents the results of these analyses. The scope of this study is to provide a concise biostratigraphic framework that is developed from the calcareous nannofossils and based on a limited number of samples. It is not intended to be a comprehensive regional study.

Age assignments are mostly made according to the zonation scheme of Bukry (Bukry, 1975; Okada and Bukry, 1980), with minor modifications where a given zonation proved inadequate or unsuitable. One such case is Pleistocene, but it was not sampled in sufficient detail to present serious problems. A second instance is the Miocene/Pliocene boundary, which, according to the best data available, should probably be placed at the extinction of Discoaster quinqueramus (Gartner et al., 1983). A third area of difficulty introduced by Bukry's zonation is his use of the beginning or end of an acme to delimit zones. The beginning or end of an acme can be rendered meaningless by differential dissolution because the abundance of a species can be decreased or enhanced greatly depending on its susceptibility to dissolution. Finally, the first appearance of Sphenolithus distentus cannot be used as a marker where indicated by Bukry because the species occurs consistently at a much lower level.

One recommendation for improving existing zonations of the middle Miocene where several of the designated markers are notably sporadic and unreliable is to use the

\footnotetext{
${ }^{1}$ Mayer, L., Theyer, F., et al., Init. Repts. DSDP, 85: Washington (U.S. Govt. Printing Office). 77843 .

Mayer, L., Theyer, F., et al., Init. Repts. DSDP, 85: Washington (U.S. Govt. Printing
}

highest occurrence of Coronocyclus nitescens as a marker. This species is distinctive and hence easy to recognize and identify. It is consistent in its occurrence in pelagic and hemipelagic sediments and relatively resistant to dissolution. Although the species is rarely a major constituent of the assemblage, it is in all other respects a nearly ideal marker species. The bio-horizon marked by the last or highest occurrence of this species is above the highest occurrence of Sphenolithus heteromorphus and below the first appearance of Catinaster coalitus. It probably occurs within the lower part of magnetic polarity epoch 13 and has an age of about 13 Ma. In Hole 572D C. nitescens last occurs somewhat below the $\mathrm{CN} 5 \mathrm{a} / \mathrm{CN} 5 \mathrm{~b}$ zonal boundary; in Holes 573B and 574 its last occurrence is imprecisely known because the accepted marker species are not present. In Hole $574 \mathrm{C}$ the highest occurrence of the species may not have been recovered, and in Hole $575 C$. nitescens disappears just below the CN5a/ CN5b zonal boundary. It should be noted that the apparent inconsistencies in the highest occurrence of C. $n i$ tescens can partly be explained by inconsistent occurrences of designated markers but could also reflect the relatively wide sample spacing of this study.

A summary overview of the zonal and age assignments of the cores from Leg 85 is given on Table 1.

\section{METHODS}

Smear slides were prepared for each sample from unprocessed material. The slides were examined with a light microscope at approximately $\times 1600$ magnification using cross-polarized light, differential interference constrast, and phase contrast optics. Abundance estimates were made on optimum density areas of the slides, that is, areas where most of the field was covered with sample material without appreciable piling of specimens or sample material. The abundance code translates as follows: A (abundant), usually more than 10 specimens occurring per field; $\mathrm{C}$ (common), 1 to 10 specimens per field; $\mathrm{F}$ (few), 1 specimen per 1 to 10 fields; $\mathrm{R}$ (rare), 1 specimen per more than 10 fields.

\section{SITE 572}

\section{Holes 572A and 572C}

Forty-nine samples were examined from Site 572. Seventeen samples are from Holes 572A and 572C; four of 


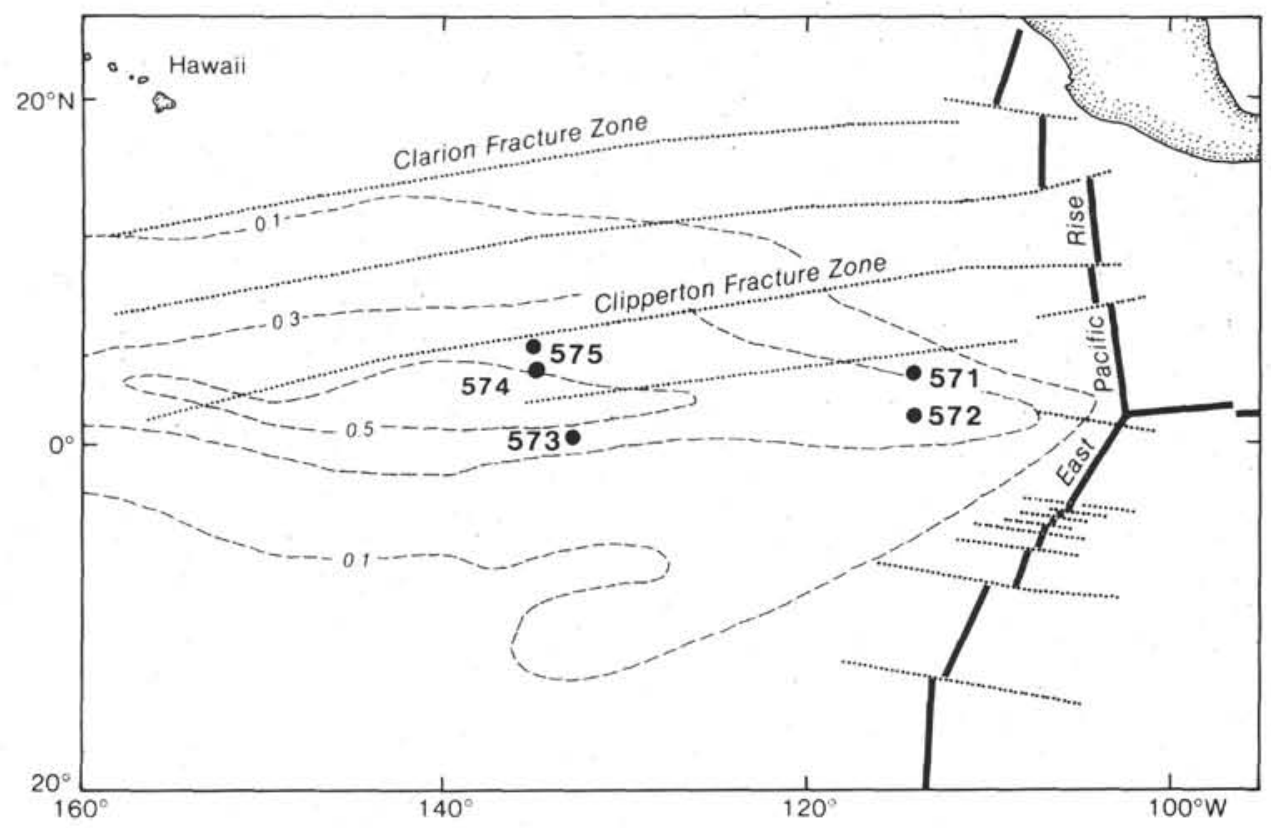

Figure 1. Location of DSDP Leg 85 sites in the eastern equatorial Pacific. Contours show sediment thickness in seconds (two-way traveltime).

these are core-catcher samples. The two samples from Hole 572C (Cores 1 and 2) are combined on one chart with fifteen samples from Hole 572A (Cores 3 through 17). The calcareous nannofossil checklist for these samples is given in Table 2. Preservation of nannofossils is fair to poor throughout the interval, and the biostratigraphy lacks sharp definition because marker species are usually present only sporadically. Nevertheless, the age determinations given are considered accurate and reliable.

Samples 572C-1, CC through 572A-3,CC are of Pleistocene age (Zones $\mathrm{CN} 14$ and $\mathrm{CN} 13$ ) and extend from the middle to the upper Pleistocene in the topmost sample and down to the lower Pleistocene in the lowermost sample. Conspicuous markers include Pseudoemiliania lacunosa and Calcidiscus tropicus $\left(=C\right.$. macintyrei) ${ }^{3}$

Sample 572A-4-5, 139-140 cm is uppermost Pliocene; it contains the lone asterolith species Discoaster brouwe$r i$ characteristic of this level (Zone CN12d). The Pliocene extends through Core 10 (Sample 572A-10-7, 40-41 $\mathrm{cm})$, the Miocene/Pliocene boundary being in the next lower core. The Pliocene succession is complete, although poor preservation prevents recognition of all subzones. Zones 12,11 , and 10 are, however, recognizable as distinct units.

Sample 572A-11-6, 140-141 cm contains $D$. quinqueramus and thus is assigned to the uppermost Miocene D. quinqueramus Zone (Zone CN9). This zone continues to the bottom of the section (Sample 572A-17-6, 8-9 cm) where the presence of Amaurolithus amplificus indicates an age probably not older than Zone CN9b, which corresponds to the upper part of the $D$. quinqueramus Zone.

\footnotetext{
${ }^{3}$ The name Calcidiscus tropicus (Kamptner) is used in preference to C. macintyrei (Bramlette and Bukry). The latter is considered a junior synonym (Gartner et al., 1983).
}

\section{Hole 572D}

The 32 samples from Hole 572D extended from the lower Pliocene (Zone CN10) to the lower middle Miocene (Zone CN4) (Table 3). Poor preservation makes accurate biostratigraphic subdivision of this hole difficult, although most of the zones and several subzones can be recognized. The Pliocene/Miocene boundary is tentatively placed within Core 5 because the sample immediately above it (Sample 4,CC) contains the birefringent Ceratolithus armatus, whereas the base of the next lower core (Sample 5,CC) lacks birefringent ceratoliths. Discoaster quinqueramus, the extinction of which marks the top of the Miocene, was encountered only lower (Sample 8, CC) where it co-occurs with $D$. loeblichii, a species that does not occur above the middle part of the upper Miocene.

Within the upper Miocene Subzones 9b, 9a, and $8 b$ are recognizable, but below that zones and subzones are less clearly distinguishable. The marker species $D$. hamatus and Catinaster coalitus (for Zones CN7 and CN6, respectively) are very rare and both occur in only one (and the same) sample $(15, \mathrm{CC})$. Immediately below Zone CN6, markers are lacking until $D$. kugleri is encountered in Samples 19,CC and 21,CC. This marks Zone CN5b, the $D$. kugleri Subzone. The next lower zone (CN5a) has no distinctive marker of its own, but its lower limit is recognizable by the last occurrence of Sphenolithus heteromorphus (Sample 28,CC), which continues to the bottom of the section (Sample 32,CC).

\section{SITE 573}

\section{Hole 573}

Nineteen core-catcher samples were examined from Hole 573 (Table 4). Calcareous nannofossils are common to abundant in all samples, but preservation is most- 
Table 1. Summary of zonal and age assignments of Leg 85 cores based on calcareous nannofossils from Holes 572 through 575. Nannofossil zonal numbers are those of Okada and Bukry (1980). For more detailed age assignments see Tables 2 through 9 .

\begin{tabular}{|c|c|c|c|c|c|c|c|c|c|c|}
\hline Age & & $\begin{array}{l}\text { Nannofossil } \\
\text { zones }\end{array}$ & $572 \mathrm{~A}$ & $572 \mathrm{C}$ & $572 \mathrm{D}$ & 573 & 573B & $574 \mathrm{C}$ & 575 & $575 \mathrm{~A}$ \\
\hline Pleisto & & $\begin{array}{c}\mathrm{CN} 15 \\
\text { to } \\
\mathrm{CN} 13\end{array}$ & $3, \mathrm{CC}$ & $\begin{array}{l}1, \mathrm{CC} \\
2, \mathrm{CC}\end{array}$ & & $\begin{array}{c}1, \mathrm{CC} / \\
3, \mathrm{CC}\end{array}$ & & & & \\
\hline Plioce & & $\mathrm{CN} 12$ & $\begin{array}{l}4, \mathrm{CC} \\
5, \mathrm{CC} \\
\end{array}$ & & & $\begin{array}{l}4, \mathrm{CC} \\
6, \mathrm{CC}\end{array}$ & & & $1, \mathrm{CC}$ & \\
\hline & & $\begin{array}{c}\mathrm{CN} 11 \\
\text { to } \\
\mathrm{CN} 10\end{array}$ & $\begin{array}{l}6, \mathrm{CC} \\
10-7\end{array}$ & & $1, \mathrm{CC} / 4, \mathrm{CC}$ & $\begin{array}{l}7, \mathrm{CC} \\
9, \mathrm{CC}\end{array}$ & & & $2, \mathrm{CC}$ & \\
\hline & late & CN9 & $\begin{array}{l}11-6 \\
17-6\end{array}$ & & $\begin{array}{l}5, \mathrm{CC} \\
7, \mathrm{CC}\end{array}$ & $\begin{array}{l}10, \mathrm{CC} \\
18, \mathrm{CC}\end{array}$ & & & $3, \mathrm{CC}$ & \\
\hline & & CN8 & & & $8, \mathrm{CC}$ & $19, \mathrm{CC}$ & $1, \mathrm{CC} / 4, \mathrm{CC}$ & & & \\
\hline & & $\mathrm{CN} 7$ & & & & & $5, \mathrm{CC}$ & & & \\
\hline & & CN6 & & & & & & & & \\
\hline Miocene & middle & CN5 & & & $27, \mathrm{CC}$ & & $8, \mathrm{CC}$ & $1, \mathrm{CC}$ & $7, \mathrm{CC}$ & \\
\hline & . & $\mathrm{CN} 4$ & & & $\begin{array}{l}28, \mathrm{CC} \\
32, \mathrm{CC}\end{array}$ & & $9, \mathrm{CC}$ & $2, \mathrm{CC}$ & $\begin{array}{c}8, \mathrm{CC} \\
11, \mathrm{CC}\end{array}$ & $1, \mathrm{CC}$ \\
\hline & & $\mathrm{CN} 3$ & & & & & $13, \mathrm{CC}$ & $3, \mathrm{CC}$ & & $5, \mathrm{CC}$ \\
\hline & & CN2 & & & & & $14, \mathrm{CC}$ & $4, \mathrm{CC}$ & & $\begin{array}{l}6, \mathrm{CC} \\
9, \mathrm{CC}\end{array}$ \\
\hline & & $\mathrm{CN} 1$ & & & & & $15, \mathrm{CC}$ & $5, \mathrm{CC}$ & & $10, \mathrm{CC}$ \\
\hline & 78 & & & & & & $20, \mathrm{CC}$ & $17, \mathrm{CC}$ & & $33, \mathrm{CC}$ \\
\hline & late & CP19 & & & & & $21, C C$ & $18, \mathrm{CC}$ & & \\
\hline & & & & & & & $30, \mathrm{CC}$ & $20, \mathrm{CC}$ & & \\
\hline Oligocene & & CP18 & & & & & $31, \mathrm{CC}$ & $21, \mathrm{CC}$ & & \\
\hline & & CP17 & & & & & $37, \mathrm{CC}$ & $28, \mathrm{CC}$ & & \\
\hline & & CP16 & & & & & $\begin{array}{l}38, \mathrm{CC} \\
40, \mathrm{CC}\end{array}$ & $\begin{array}{l}29, \mathrm{CC} \\
34, \mathrm{CC}\end{array}$ & & \\
\hline Eocene & late & CP15 & & & & & & $35, \mathrm{CC}$ & & \\
\hline
\end{tabular}

ly fair to poor. Only in the uppermost three core-catcher samples is nannofossil preservation fair to good. Both dissolution and overgrowth are noticeable, and the low species diversity of some samples suggests that some species have probably been removed by corrosion.

The 19 samples extend from the upper Pleistocene at the top (Zone CN14b) to the upper Miocene Discoaster neohamatus Zone (Zone CN8) at the bottom. All of the intervening zones can be recognized, and in several cases subzones can be distinguished as well. The Pliocene/Pleistocene boundary is placed within Core 4 ; the base of that core contains the upper Pliocene marker $D$. brouweri. The next higher sample $(3, \mathrm{CC})$ lacks discoasters. The Pliocene zones appear to be of uneven spans (e.g., CN11 and CN12), which could be the result of poor preservation of some marker species or notably different sediment accumulation rates, possibly stemming from differential dissolution of biogenic carbonate. However, it may be entirely an artifact introduced by the wide spacing between adjacent samples.

The Miocene/Pliocene boundary is placed at the highest occurrence of $D$. quinqueramus, which is within Core 10 . The upper Miocene D. quinqueramus Zone (Zone CN9) is more expanded than the Pliocene zones, although nannofossil preservation is not notably better.

\section{Hole 573B}

Forty samples, all but one of them core-catcher samples, were examined from Hole 573B (Table 5), and these extend from the upper Miocene at the top to upper Oli- 
Table 2. Occurrence of calcareous nannofossils in core-catcher samples, DSDP Holes 572A and 572C, Leg 85.

\begin{tabular}{|c|c|c|c|c|c|c|c|c|c|c|c|c|c|c|c|c|c|}
\hline Age & $\begin{array}{c}\text { Sample } \\
\text { (interval in } \mathrm{cm} \text { ) }\end{array}$ & 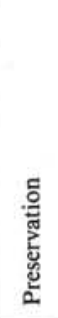 & 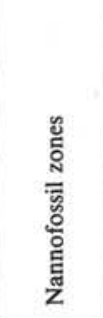 & 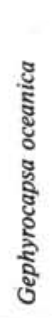 & 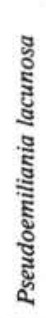 & 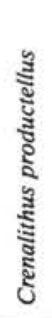 & 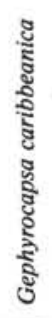 & 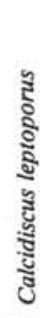 & 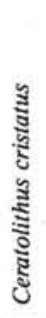 & 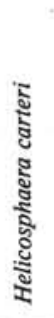 & 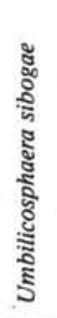 & 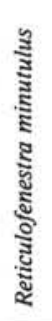 & 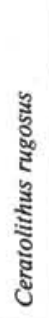 & 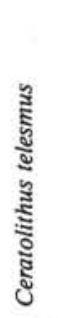 & 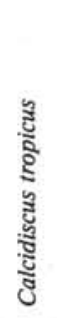 & 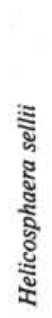 & 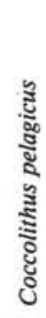 \\
\hline Pleist. & $\begin{array}{r}572 \mathrm{C}-1, \mathrm{CC} \\
2, \mathrm{CC} \\
572 \mathrm{~A}-3, \mathrm{CC} \\
\end{array}$ & $\begin{array}{l}\text { F } \\
\text { F-P } \\
\text { F-P }\end{array}$ & $\begin{array}{c}\mathrm{CN} 14 \\
\text { to } \\
\mathrm{CN} 13\end{array}$ & $\begin{array}{l}\mathrm{C} \\
\mathrm{F}\end{array}$ & $\begin{array}{l}\text { C } \\
\text { A } \\
\text { A }\end{array}$ & $\begin{array}{l}\mathrm{A} \\
\mathrm{C}\end{array}$ & $\begin{array}{l}\mathrm{C} \\
\mathrm{C} \\
\mathrm{F}\end{array}$ & $\begin{array}{l}\mathrm{C} \\
\mathrm{C} \\
\mathrm{C}\end{array}$ & $\begin{array}{l}\mathrm{F} \\
\mathrm{R}\end{array}$ & $\begin{array}{l}\text { C } \\
\text { F } \\
\text { C }\end{array}$ & $\begin{array}{l}\mathrm{F} \\
\mathrm{C} \\
\mathrm{C}\end{array}$ & $\begin{array}{l}\text { C } \\
\text { A }\end{array}$ & $\begin{array}{l}\mathrm{F} \\
\mathrm{F}\end{array}$ & F & $\begin{array}{l}\mathrm{C} \\
\mathrm{C}\end{array}$ & C & F \\
\hline \multirow{3}{*}{ Pliocene } & $\begin{array}{l}4-5,139-140 \\
5, \mathrm{CC}, 14-15\end{array}$ & $\begin{array}{l}\text { F-P } \\
\text { F-P }\end{array}$ & $\mathrm{CN} 12 \frac{\mathrm{d}}{\mathrm{a}}$ & & C & & & F & $\mathrm{F}$ & $\begin{array}{l}\mathrm{F} \\
\mathrm{F}\end{array}$ & & $\begin{array}{l}\mathrm{A} \\
\mathrm{F}\end{array}$ & $\begin{array}{l}\mathrm{R} \\
\mathrm{F}\end{array}$ & & $\begin{array}{l}\text { A } \\
\text { A }\end{array}$ & $\begin{array}{l}\mathrm{A} \\
\mathrm{F}\end{array}$ & A \\
\hline & $\begin{array}{l}6-6,140-141 \\
7-6,100-101 \\
8-6,59-60\end{array}$ & $\begin{array}{c}\text { F-P } \\
P \\
P\end{array}$ & CN11 & & F & & & & $\begin{array}{l}\mathrm{F} \\
\mathrm{R}\end{array}$ & & & $\begin{array}{l}\text { A } \\
\text { C } \\
\text { A }\end{array}$ & $\begin{array}{l}\mathrm{F} \\
\mathrm{R}\end{array}$ & & $\begin{array}{l}\text { A } \\
\text { C } \\
\text { C }\end{array}$ & & $\begin{array}{l}\mathrm{C} \\
\mathrm{F}\end{array}$ \\
\hline & $\begin{array}{l}9-6,140-144 \\
10-7,40-41\end{array}$ & $\begin{array}{l}\text { P-F } \\
\text { F-P }\end{array}$ & CN10 & & & $\begin{array}{l}\mathrm{C} \\
\mathrm{F}\end{array}$ & & $\mathrm{F}$ & & $\begin{array}{l}\mathrm{C} \\
\mathrm{C}\end{array}$ & & $\begin{array}{l}\text { A } \\
\text { A }\end{array}$ & & & $\begin{array}{l}\mathrm{C} \\
\mathrm{C}\end{array}$ & & $\mathrm{R}$ \\
\hline Miocene & $\begin{array}{l}11-6,140-141 \\
12-6,140-141 \\
13-6,140-141 \\
14-6,140-141 \\
15-6,100-101 \\
16-6,40-41 \\
17-6,8-9\end{array}$ & $\begin{array}{l}\text { P-F } \\
\text { P-F } \\
\text { P-F } \\
\text { P-F } \\
\text { P-F } \\
\text { P-F } \\
\text { F-P }\end{array}$ & CN9 & & & & & $\begin{array}{l}\mathrm{F} \\
\mathrm{F} \\
\mathrm{C} \\
\mathrm{F} \\
\mathrm{C} \\
\mathrm{R}\end{array}$ & & $\begin{array}{l}\mathrm{R} \\
\mathrm{C} \\
\mathrm{F} \\
\mathrm{C} \\
\mathrm{R} \\
\mathrm{R} \\
\mathrm{F}\end{array}$ & & $\begin{array}{l}\text { A } \\
\text { A } \\
\text { A } \\
\text { A } \\
\text { A } \\
\text { C } \\
\text { C }\end{array}$ & & & $\begin{array}{l}\mathrm{R} \\
\mathrm{C} \\
\mathrm{C} \\
\mathrm{C}\end{array}$ & R & $\begin{array}{l}\text { C } \\
\text { F } \\
\text { F } \\
\text { A }\end{array}$ \\
\hline
\end{tabular}

Note: $\mathrm{A}=$ abundant $\mathrm{C}=$ common; $\mathrm{F}=$ few; $\mathrm{R}=$ rare. See text for further explanation. Preservation: $\mathrm{F}=$ fair; $\mathrm{P}=$ poor.

gocene at the bottom of this hole. Not all intervening zones are identifiable, again resulting from poor preservation and the absence of certain key marker species. The youngest zone represented is the upper Miocene Discoaster neohamatus Zone (Zone CN8). The middle Miocene Zones CN7, CN6, and CN5 cannot be differentiated, although all three may be represented in the interval of Cores 5 through 8. The two critical markers for this interval, Catinaster coalitus and D. hamatus, were not found in the samples. Zones CN4 and CN3, which are the Sphenolithus heteromorphus and Helicosphaera ampliaperta Zones, together cover the interval of Cores 9 through 13. The marker species for differentiating these two zones, however, were not considered reliable over this interval.

The Oligocene/Miocene boundary cannot be placed precisely (it does not correspond to a nannofossil biohorizon used in Bukry's zonation), although the interval in which it is contained, the Triquetrorhabdulus carinatus Zone (Zone CN1), is well developed from Cores 15 through 20. The Oligocene Zones CP19 through CP16, which are the Sphenolithus ciperoensis through Helicosphaera reticulata Zones, are represented from Cores 21 through 40 . Zones CP18 and CP17 cannot be separated because the marker species Sphenolithus distentus extends well below the next lower marker, an apparent internal inconsistency in Bukry's zonation. There is a break in the range of S. distentus (Cores 33 and 34), and it is tempting to place the zonal boundary at this level; however, that interpretation of the data would be incorrect.

\section{SITE 574}

Two suites of samples were examined from Site 574: one from Hole 574 consists of 30 core-catcher samples, and the second from Hole $574 \mathrm{C}$ consists of 35 corecatcher samples. The two sections combined extend from the Pleistocene at the top of Hole 574 to the uppermost Eocene at the bottom (Core 35) of Hole 574C. The section appears to be continuous over the entire interval to the extent that it can be resolved given the sample spacing and the poor preservation of much of the section.

\section{Hole 574}

The 30 samples from Hole 574 are from the core catchers of each of the 31 successive cores, except for Core 23 from which no sample was available (Table 6). The upper Neogene (upper Miocene, Pliocene, and Pleistocene) is represented in only the uppermost 7 cores (Zones CN8 through CN14), whereas the middle Miocene is represented in Cores 8 through 31 (Zones CN4 through CN7). This great difference in thickness probably indicates a pronounced change in sedimentation rates; however, the preservation of the nannofossils is poor throughout and thus does not reflect the different sedimentation rates perfectly. Preservation is rendered poor by both dissolution of some species and overgrowth of others, often within the same sample.

The Pleistocene is represented in Core 1 and possibly the upper part of Core 2, although the base of Core 2 is Pliocene as are Cores 3 through 5. The three zones of 


\begin{tabular}{|c|c|c|c|c|c|c|c|c|c|c|c|c|c|c|c|c|c|c|c|c|c|}
\hline 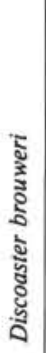 & 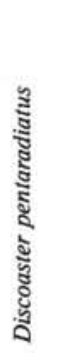 & 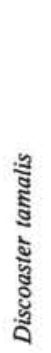 & 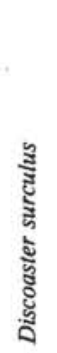 & 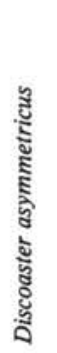 & 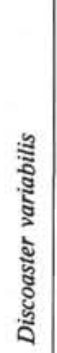 & 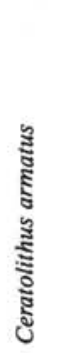 & 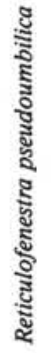 & 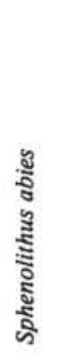 & 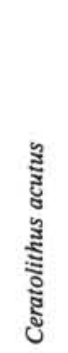 & 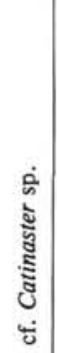 & 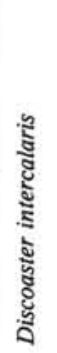 & 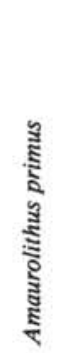 & 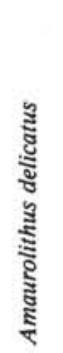 & 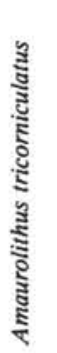 & 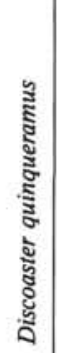 & 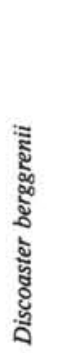 & 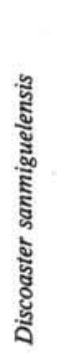 & 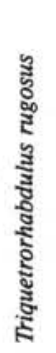 & 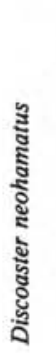 & 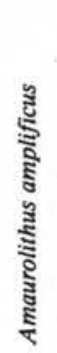 & 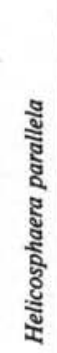 \\
\hline $\begin{array}{l}\text { F } \\
\text { A }\end{array}$ & A & $\mathbf{R}$ & F & R & F & & & & & & & & & & & & & & & & \\
\hline $\begin{array}{l}\mathrm{F} \\
\mathrm{C} \\
\mathrm{C}\end{array}$ & F & & F & R & $\begin{array}{l}\mathrm{F} \\
\mathrm{C} \\
\mathrm{C}\end{array}$ & $\mathbf{R}$ & $\begin{array}{l}\mathbf{R} \\
\mathrm{C} \\
\mathrm{C}\end{array}$ & $\begin{array}{l}\mathrm{F} \\
\mathrm{C}\end{array}$ & cf. & & & & & & & & & & & & \\
\hline $\begin{array}{l}\mathrm{C} \\
\mathrm{F}\end{array}$ & $\begin{array}{l}\mathrm{C} \\
\mathrm{F}\end{array}$ & $\mathbf{R}$ & $\begin{array}{l}F \\
F\end{array}$ & & $\begin{array}{l}\text { F } \\
\text { F }\end{array}$ & $\mathbf{R}$ & $\begin{array}{l}\text { A } \\
\text { C }\end{array}$ & $\begin{array}{l}\mathrm{C} \\
\mathrm{C}\end{array}$ & $\begin{array}{l}\mathrm{R} \\
\mathrm{R}\end{array}$ & & $\begin{array}{l}\mathbf{F} \\
\mathbf{R}\end{array}$ & $\mathbf{R}$ & R & $\mathbf{R}$ & & & & & & & \\
\hline $\begin{array}{l}\text { C } \\
\text { R } \\
\text { F }\end{array}$ & $\begin{array}{l}\mathbf{R} \\
\mathbf{F}\end{array}$ & & $\begin{array}{l}\text { C } \\
\text { R } \\
\text { F }\end{array}$ & & $\begin{array}{l}\mathrm{R} \\
\mathrm{C} \\
\mathrm{R}\end{array}$ & & $\begin{array}{l}\text { C } \\
\text { C } \\
\text { C } \\
\text { A } \\
\text { C } \\
\text { C } \\
\text { A }\end{array}$ & $\begin{array}{l}\text { C } \\
\text { C } \\
\text { A } \\
\text { A } \\
\text { A } \\
\text { C } \\
\text { C }\end{array}$ & & & $\mathbf{R}$ & $\begin{array}{c}\mathrm{R} \\
\mathrm{R} \\
\mathrm{F} \\
\mathrm{R} \\
\text { cf. }\end{array}$ & $\mathbf{R}$ & & $\begin{array}{l}\mathrm{R} \\
\mathrm{R} \\
\\
\mathrm{R} \\
\mathrm{C} \\
\mathrm{F} \\
\mathrm{R}\end{array}$ & $\begin{array}{l}\mathrm{F} \\
\mathrm{R} \\
\mathrm{R} \\
\mathrm{F} \\
\mathrm{R}\end{array}$ & C & $\mathbf{R}$ & $\mathbf{R}$ & $\mathbf{R}$ & $\mathbf{R}$ \\
\hline
\end{tabular}

the Pliocene (CN12 through $\mathrm{CN} 10 \mathrm{~b})$ are represented but subzones cannot be identified consistently. The upper Miocene zones can only be identified imperfectly. Subzone $\mathrm{CN10}$ a was not identified, although it may be present within an unsampled interval of Core 6 . The bottom of Core 6 (Sample 6,CC) belongs to Zone CN9. The interval from the Discoaster neohamatus Zone through the D. exilis Zone (Zones CN8, CN7, CN6, and CN5) is reasonably complete, but the boundary between the lower two zones is unclear because of the absence in the samples of the marker species Catinaster coalitus.

The boundary between Zone CN5 and CN4 is also unclear because of the rare but unambiguous occurrence of Sphenolithus heteromorphus in Core 16. This species is not found in the three immediately subjacent cores but does occur in much greater abundance from Cores 20 through 31 . Thus the occurrence of the species in Core 16 is suspect. If the occurrence of Sphenolithus heteromorphus in Core 16 is spurious, as assumed here, then the sedimentation rate change in the section implied by the spacing of nannofossil bio-horizons occurred somewhat later and was less intense than indicated by the actually documented last occurrence of Sphenolithus heteromorphus.

\section{Hole 574C}

The 35 core-catcher samples from Hole $574 \mathrm{C}$ (Table 7) extend from the middle Miocene Sphenolithus heteromorphus Zone (CN5) to the upper Eocene Discoaster barbadiensis Zone (CP15). Although not all zones and subzones can be clearly identified, primarily resulting from poor preservation of marker species, the section appears to be continuous. The lower to middle Miocene
Helicosphaera ampliaperta Zone (CN3) cannot be clearly identified. Similarly the Miocene/Oligocene boundary remains somewhat ambiguous because it is not possible to clearly identify the marker horizon, the acme of Cyclicargolithus abisectus. The boundary is placed within Core 17; however, it could be somewhat higher because specimens intermediate between $C$. abisectus and the smaller $C$. floridanus are common.

The Paleogene interval from Sphenolithus ciperoensis Zone through the $D$. barbadiensis Zone (Zones CP19 through CP15) are well represented. The boundary between the $S$. distentus Zone (CP18) and the $S$. predistentus Zone (CP17), however, cannot be determined because the marker species $S$. distentus ranges well below the level implied by the zonation scheme. Clearly the Oligocene zonal succession merits further study, including identification of some additional nannofossil marker species.

The Eocene/Oligocene boundary is within Core 35 because the base of that core contains the distinctive $D$. barbadiensis and $D$. saipanensis, both characteristic of the upper Eocene, along with several other upper Eocene species.

\section{SITE 575}

Two suites of sample were examined from Site 575: one from Hole 575 consists of 11 samples, and the second from Hole 575A consists of 33 samples. All of the samples are from core-catcher material. The total interval represented by the two sections includes part of the Pliocene and nearly all of the Miocene. Pleistocene nannofossil assemblages were not identified; the youngest sample, although nearly barren, appears to be Pliocene 
Table 3. Occurrence of calcareous nannofossils in core-catcher samples, DSDP Hole 572D, Leg 85.

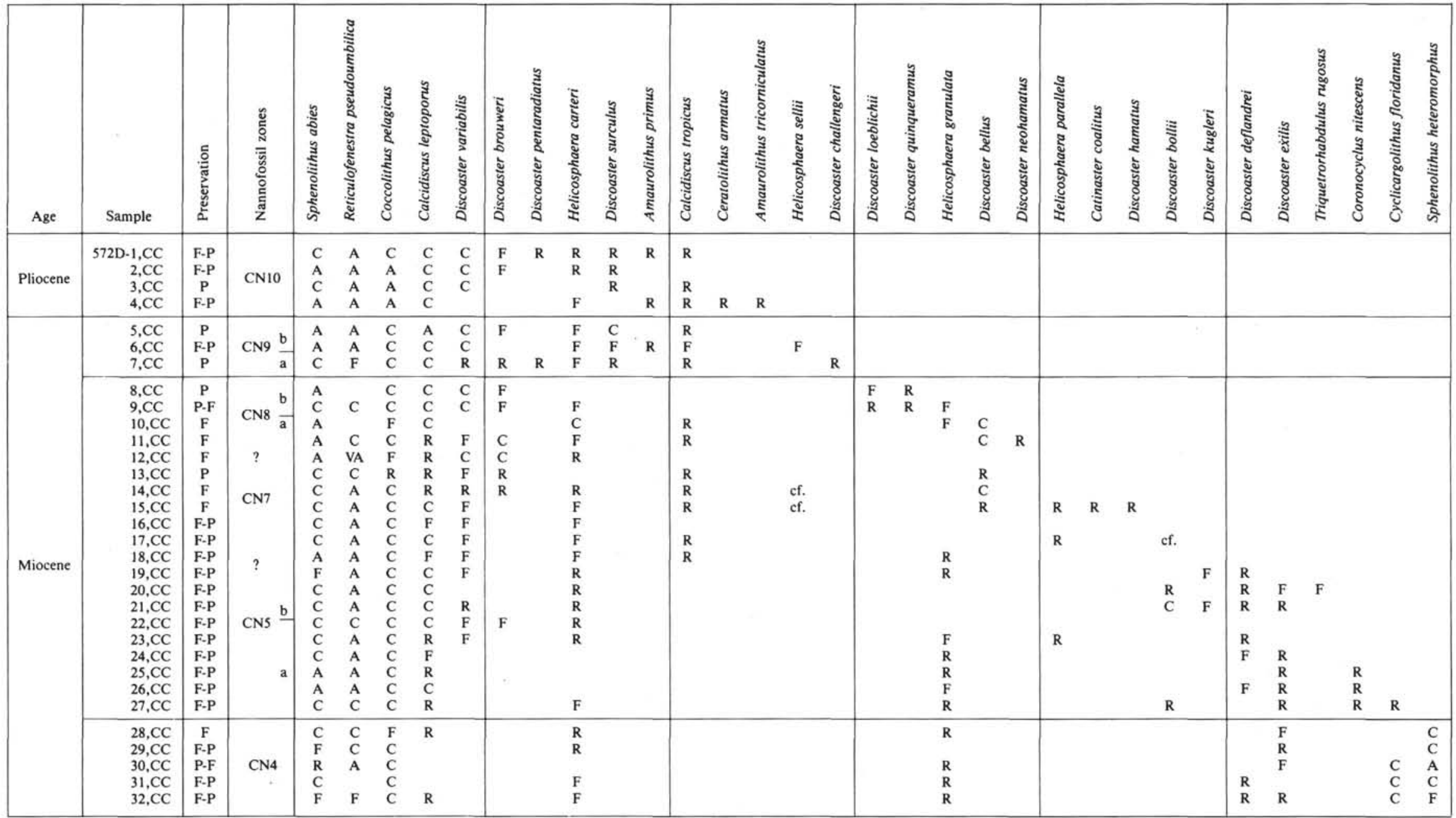

Note: Symbols as in Table 2 
Table 4. Occurrence of calcareous nannofossils in core-catcher samples, DSDP Hole 573, Leg 85.

\begin{tabular}{|c|c|c|c|c|c|c|c|c|c|c|c|c|c|c|c|c|c|c|c|c|c|c|c|c|c|c|}
\hline Age & Sample & 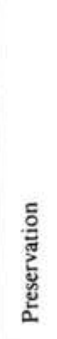 & 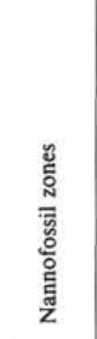 & 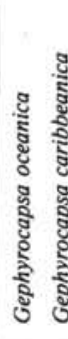 & 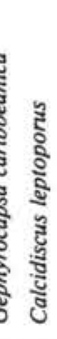 & 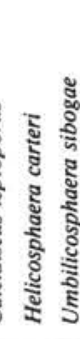 & 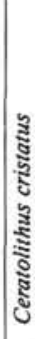 & 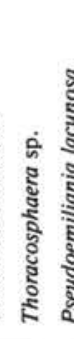 & 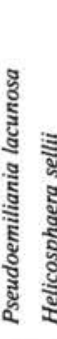 & 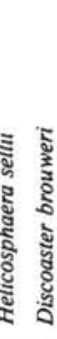 & 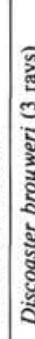 & 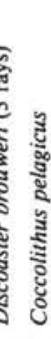 & 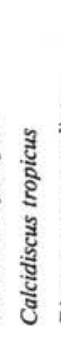 & 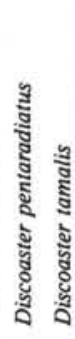 & 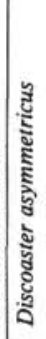 & 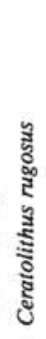 & 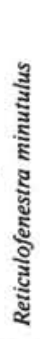 & 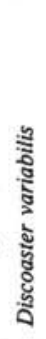 & 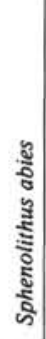 & 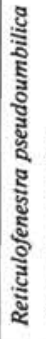 & 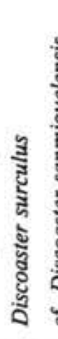 & 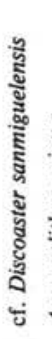 & 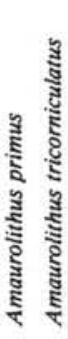 & 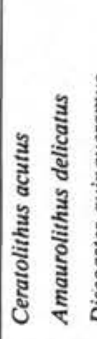 & 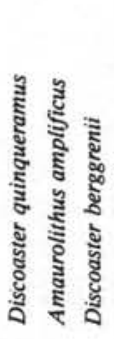 & 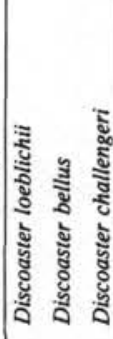 \\
\hline Pleist. & $\begin{array}{r}573-1, \mathrm{CC} \\
2, \mathrm{CC} \\
3, \mathrm{CC} \\
\end{array}$ & $\begin{array}{l}F-G \\
F-G \\
F-G \\
\end{array}$ & $\begin{array}{l}\mathrm{CN}_{14} \frac{\mathrm{b}}{\mathrm{a}} \\
\mathrm{CN} 13\end{array}$ & $\begin{array}{ll}\mathrm{A} & \mathrm{A} \\
\mathrm{A} & \mathrm{A} \\
\mathrm{C} & \mathrm{A} \\
\end{array}$ & $\begin{array}{ll}A & C \\
A & C \\
A & C \\
\end{array}$ & $\begin{array}{ll}F & R \\
F & \\
F & R\end{array}$ & $\begin{array}{l}\mathrm{R} \\
\mathrm{R} \\
\mathrm{R}\end{array}$ & C A & $\begin{array}{ll}A & \\
A & F\end{array}$ & $F$ & & & & & & & & & & & . & & & & & \\
\hline \multirow{3}{*}{ Pliocene } & $\begin{array}{l}4, \mathrm{CC} \\
5, \mathrm{CC} . \\
6, \mathrm{CC}\end{array}$ & $\begin{array}{l}\mathrm{F} \\
\mathrm{F} \\
\mathrm{P}\end{array}$ & $\mathrm{CN} 12$ & & $\begin{array}{l}\text { F } \\
\text { F } \\
\text { A }\end{array}$ & $\begin{array}{l}\mathrm{R} \\
\mathrm{C} \\
\mathrm{F}\end{array}$ & $\mathbf{R}$ & F & $\begin{array}{l}\text { A } \\
\text { C }\end{array}$ & $\begin{array}{l}\mathrm{C} \\
\mathrm{F} \\
\mathrm{F}\end{array}$ & $\begin{array}{l}\mathrm{R} \\
\mathrm{R}\end{array}$ & $\begin{array}{l}\mathrm{C} \\
\mathrm{C}\end{array}$ & $\begin{array}{l}\mathrm{C} \\
\mathrm{C}\end{array}$ & $\begin{array}{ll}\mathrm{F} & \mathrm{F} \\
\mathrm{R} & \end{array}$ & $\begin{array}{l}R \\
R\end{array}$ & $\mathrm{R}$ & A & $\mathrm{F}$ & & & & & & & & \\
\hline & $7, \mathrm{CC}$ & $\mathrm{F}$ & CN11 & & C & $R$ & F & & & A & & C & $F$ & & $R$ & $\mathrm{R}$ & A & $\mathrm{R}$ & A & A & R R & $R$ & & & & \\
\hline & $\begin{array}{l}8, \mathrm{CC} \\
9, \mathrm{CC}\end{array}$ & $\begin{array}{l}\mathrm{F} \\
\mathrm{F}\end{array}$ & $\mathrm{CN} 10$ & & C & & F & & & C & & $\begin{array}{l}\mathrm{C} \\
\mathrm{A}\end{array}$ & $\begin{array}{l}\mathrm{C} \\
\mathrm{C}\end{array}$ & $\begin{array}{l}\mathbf{F} \\
\mathbf{R}\end{array}$ & R & $\mathrm{F}$ & A & $\begin{array}{l}\mathrm{R} \\
\mathrm{R}\end{array}$ & & $\begin{array}{l}\text { A } \\
\text { A }\end{array}$ & $\begin{array}{ll}\mathrm{F} & \mathrm{R} \\
\mathrm{C} & \end{array}$ & $\begin{array}{ll}\mathrm{R} & \mathrm{F} \\
\mathrm{F}\end{array}$ & $\begin{array}{l}R \\
R \\
R\end{array}$ & R R & & \\
\hline \multirow[t]{2}{*}{ Miocene } & $\begin{array}{l}10, \mathrm{CC} \\
11, \mathrm{CC} \\
12, \mathrm{CC} \\
13, \mathrm{CC} \\
14, \mathrm{CC} \\
15, \mathrm{CC} \\
16, \mathrm{CC} \\
17, \mathrm{CC} \\
18, \mathrm{CC}\end{array}$ & $\begin{array}{l}\text { P-F } \\
\text { F } \\
\text { F-P } \\
\text { F-P } \\
\text { F-P } \\
\text { F-P } \\
\text { F-P } \\
\text { F-P } \\
\text { F-P }\end{array}$ & $\mathrm{CN} 9-$ & & $\begin{array}{l}\text { F } \\
\text { F } \\
\text { C } \\
\text { C } \\
\text { C }\end{array}$ & $\begin{array}{l}\mathrm{R} \\
\mathrm{R} \\
\mathrm{R} \\
\mathrm{R}\end{array}$ & & & & $\begin{array}{l}\text { F } \\
\text { C } \\
\text { F } \\
\text { F } \\
\text { F } \\
\text { F } \\
\text { C } \\
\text { A }\end{array}$ & $\begin{array}{l}\mathrm{R} \\
\mathrm{R} \\
\mathrm{R}\end{array}$ & $\begin{array}{l}\text { C } \\
\text { C } \\
\text { A } \\
\text { C } \\
\text { C } \\
\text { C } \\
\text { C } \\
\text { C } \\
\text { F }\end{array}$ & $\begin{array}{l}\mathrm{C} \\
\\
\mathrm{C} \\
\mathrm{C} \\
\mathrm{C} \\
\mathrm{C} \\
\mathrm{C} \\
\mathrm{R}\end{array}$ & $\begin{array}{l}\mathrm{C} \\
\mathrm{R} \\
\mathrm{R} \\
\\
\\
\\
\end{array}$ & & & $\begin{array}{l} \\
\text { C } \\
\text { C } \\
\text { C } \\
\text { A } \\
\text { F }\end{array}$ & $\begin{array}{l}\text { C } \\
\text { R } \\
\text { C } \\
\text { F } \\
\text { F } \\
\text { F } \\
\text { C } \\
\text { A } \\
\text { A }\end{array}$ & \begin{tabular}{l|}
$\mathrm{A}$ \\
$\mathrm{C}$ \\
$\mathrm{A}$ \\
\\
$\mathrm{C}$ \\
$\mathrm{C}$ \\
$\mathrm{A}$ \\
$\mathrm{C}$
\end{tabular} & $\begin{array}{l}\text { A } \\
\text { C } \\
\text { C } \\
\\
\\
\text { R } \\
\text { R } \\
\text { A }\end{array}$ & $\begin{array}{l}\mathrm{C} \\
\mathrm{C} \\
\mathrm{F} \\
\mathrm{F} \\
\mathrm{F} \\
\mathrm{F} \\
\mathrm{F}\end{array}$ & & $\begin{array}{l}\mathrm{R} \\
\mathrm{R} \\
\mathrm{F}\end{array}$ & $\begin{array}{ll}\mathrm{R} & \mathrm{C} \\
\mathrm{R} & \mathrm{R} \\
\mathrm{R} & \mathrm{F} \\
\mathrm{R} & \mathrm{R} \\
\mathrm{R} & \mathrm{F} \\
& \\
& \\
& \mathrm{R}\end{array}$ & 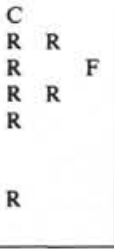 & C R \\
\hline & $19, \mathrm{CC}$ & F-P & CN8 & & C & & & & & $\mathrm{F}$ & & C & C & & & & & F & A & C & & & & & & $\mathbf{R}$ \\
\hline
\end{tabular}

Note: Symbols as in Table 2.

in age (see below). Preservation of nannofossils is rather poor throughout both sections, with notable evidence for corrosion and overgrowth.

\section{Hole 575}

Hole 575 (Table 8) extends possibly from Pliocene (the core-catcher sample of Core 1 yielded only very rare Discoaster brouweri) to the middle Miocene Sphenolithus heteromorphus Zone (CN4). From Cores 2 through 7 the $D$. quinqueramus through $D$. exilis Zones (Zones $\mathrm{CN} 10$ c through $\mathrm{CN} 5$ ) are represented, but the assemblages are too poorly preserved to allow more refined zonal assignments. Marker species are not present, and even some of the most resistant species are notably sporadic in their occurrence. Samples from Cores 8 through 11 yielded abundant Sphenolithus heteromorphus, and these cores are thus assigned to the $S$. heteromorphus Zone (CN4).

\section{Hole 575A}

The samples from Hole 575A (Table 9) extend from the Sphenolithus heteromorphus Zone (CN4) through the Triquetrorhabdulus carinatus Zone (CN1). The $S$. heteromorphus Zone grades into the subjacent Helicosphaera ampliaperta Zone (CN3) from which, however, it cannot be separated because of inadequate preservation of marker species. The next lower zone, the $S$. belemnos Zone (CN2), extends from Cores 6 through 9.
The remaining interval, Cores 10 through 33 , is assigned to the Triquetrorhabdulus carinatus Zone (CN1). Further subdivision of the relatively long Zone $\mathrm{CN} 1$ is not practical in this section because the two critical marker species Discoaster druggii and Cyclicargolithus abisectus are unreliable. The first is a generalized asterolith species that is particularly susceptible to overgrowth and alteration; the second is a solution-resistant form whose abundance is enhanced in a residual assemblage, and hence, a true acme is not necessarily recognizable.

One line of evidence that may indicate that Hole 575A penetrated into the uppermost Oligocene is the presence of Helicosphaera recta in Core 31; however, that is an isolated occurrence and may be spurious.

\section{REFERENCES}

Bukry, D., 1975. Coccolith and silicoflagellate stratigraphy, northwestern Pacific Ocean, Deep Sea Drilling Project Leg 32. In Larson, R. L., Moberly, R., et al., Init. Repts. DSDP, 32: Washington (U.S. Govt. Printing Office), 677-701.

Gartner, S., Chen, M. P., and Stanton, R. J., 1983. Late Neogene nannofossil biostratigraphy and paleoceanography of the northeastern Gulf of Mexico and adjacent areas. Mar. Micropaleontol., $8: 17-50$.

Okada, H., and Bukry, D., 1980. Supplementary modification and introduction of code numbers to the low latitude coccolith biostratigraphic zonation (Bukry, 1973; 1975). Mar. Micropalentol., 5: 321-325.

Date of Initial Receipt: 28 October 1983

Date of Acceptance: 6 April 1984 
Table 5. Occurrence of calcareous nannofossils in core-catcher samples, DSDP Hole 573B, Leg 85.

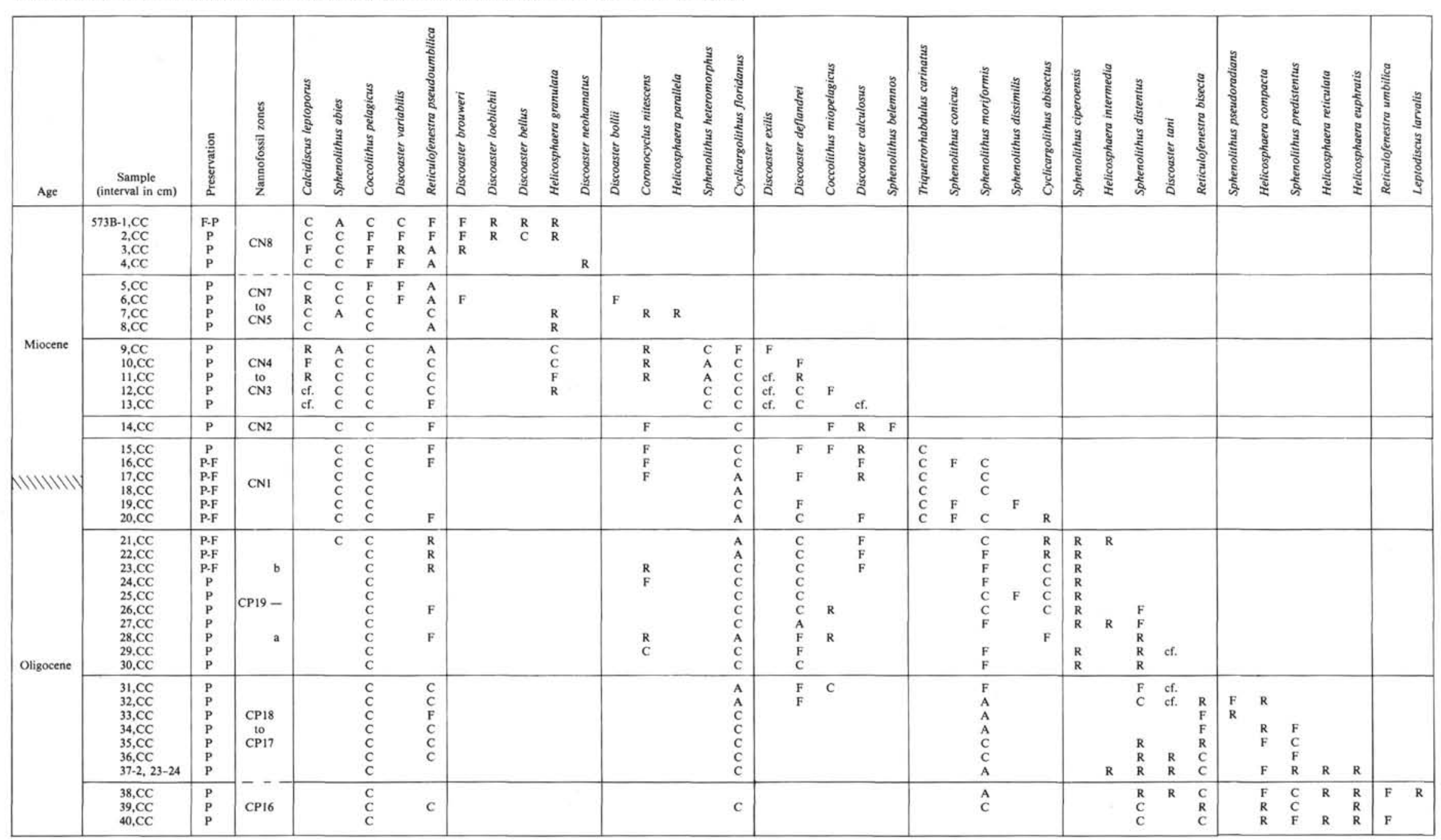

Note: Symbols as in Table 2 . 
Table 6. Occurrence of calcareous nannofossils in core-catcher samples, DSDP Hole 574, Leg 85.

\begin{tabular}{|c|c|c|c|c|c|c|c|c|c|c|c|c|c|c|c|c|c|c|c|c|c|c|c|c|c|c|c|c|c|c|c|c|c|c|c|c|c|c|c|}
\hline Age & Sample & 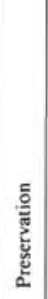 & 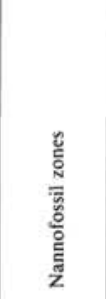 & 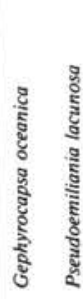 & 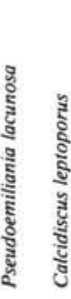 & 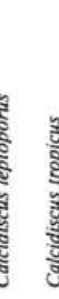 & 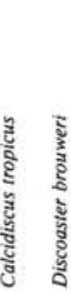 & 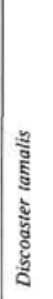 & 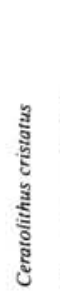 & 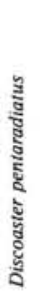 & 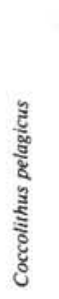 & 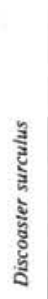 & 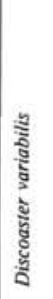 & 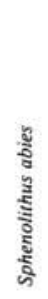 & 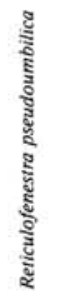 & 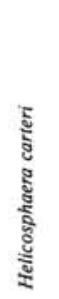 & 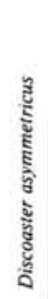 & 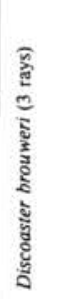 & $\begin{array}{l}\text { בूँ } \\
\text { हू } \\
\text { हूँ } \\
\text { हूँ }\end{array}$ & $\begin{array}{l}\text { है } \\
\text { है } \\
\text { है } \\
\text { है } \\
\text { है }\end{array}$ & 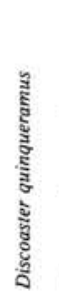 & 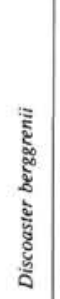 & 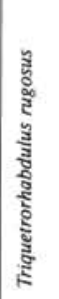 & 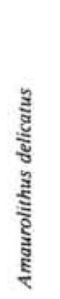 & 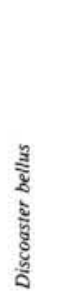 & 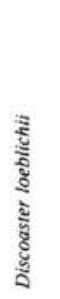 & 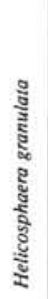 & 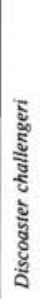 & 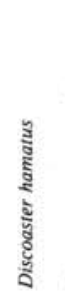 & 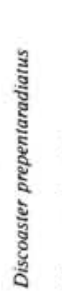 & 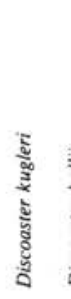 & 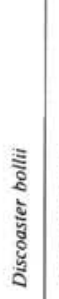 & 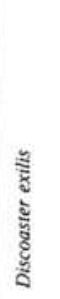 & 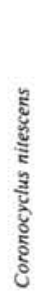 & 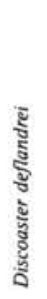 & 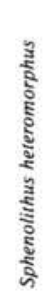 & 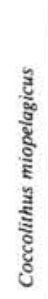 & 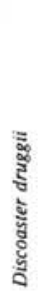 & 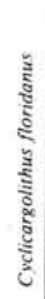 \\
\hline Pleist. & $574-1, C C$ & $\mathbf{P}$ & CN14a & $R$ & c & $\mathrm{F}$ & c & & & & & & & & & & & & & & & & & & & & & & & & & & & & & & & & \\
\hline \multirow{3}{*}{ Plio. } & $2, \mathrm{CC}$ & $\mathbf{P}$ & $\mathrm{CN} 12$ & & C & & $\mathrm{F}$ & $R$ & $R$ & $\mathrm{R}$ & $\mathrm{R}$ & $R$ & $R$ & & & & & & & & & & & & & & & & & & & & & & & & & & \\
\hline & $\begin{array}{l}3, \mathrm{CC} \\
4, \mathrm{CC} \\
\end{array}$ & $\begin{array}{l}\mathrm{P} \\
\mathrm{P}\end{array}$ & $\mathrm{CN} 11$ & & & & $\begin{array}{lll}c & c \\
c & c \\
\end{array}$ & & R & C & $\mathrm{F}$ & & R & $\begin{array}{l}\mathrm{C} \\
\mathrm{C}\end{array}$ & $\begin{array}{l}\mathrm{C} \\
\mathrm{C}\end{array}$ & $\mathbf{R}$ & $\mathrm{R}$ & $R$ & $R$ & & & & & & & & & & & & & & & & & & & & \\
\hline & $5 . \mathrm{CC}$ & P & $\mathrm{CN} 10 \mathrm{c} / \mathrm{b}$ & & & & $\mathrm{F}$ & & & $\mathrm{F}$ & F & & R & A & C & $\mathrm{R}$ & & & & $\mathrm{F}$ & & & & & & & & & & & & & & & & & & & \\
\hline \multirow{6}{*}{ Miocene } & 6.CC & $P$ & CN9 & & & & c & & & & c & & & A & & & & & & & $R$ & $F$ & $R$ & $R$ & & & & & & & & & & & & & & & \\
\hline & $7 . \mathrm{CC}$ & $\mathbf{P}$ & CN8b & & & & c & & & & c & & $\mathrm{F}$ & A & c & $\mathrm{R}$ & & & & & $R$ & & & & $\mathrm{~F}$ & $\mathrm{~F}$ & $\mathrm{~F}$ & & & & & & & & & & & & \\
\hline & $\begin{array}{l}8, \mathrm{CC} \\
9, \mathrm{CC}\end{array}$ & $\begin{array}{l}\mathrm{P} \\
\mathrm{P}\end{array}$ & $\mathrm{CN} 7$ & & & & $\begin{array}{ll}\mathrm{C} & \mathrm{C} \\
\mathrm{F} & \mathrm{C}\end{array}$ & & & & c & & $\begin{array}{l}\mathrm{C} \\
\mathrm{C}\end{array}$ & $\begin{array}{l}\mathrm{R} \\
\mathrm{A}\end{array}$ & $\begin{array}{l}\mathrm{C} \\
\mathrm{C}\end{array}$ & & & R & & & A & & $\mathrm{F}$ & & & & & & $\begin{array}{l}\text { ef. } \\
\mathrm{R}\end{array}$ & $R$ & & & & & & & & & \\
\hline & $\begin{array}{l}10, \mathrm{CC} \\
11, \mathrm{CC} \\
12, \mathrm{CC} \\
13, \mathrm{CC} \\
14, \mathrm{CC} \\
15, \mathrm{CC} \\
16, \mathrm{CC}\end{array}$ & $\begin{array}{l}\mathrm{P} \\
\mathrm{P} \\
\mathrm{P} \\
\mathrm{P} \\
\mathrm{P} \\
\mathrm{P} \\
\mathrm{P}\end{array}$ & $\begin{array}{c}\text { CN6 } \\
\text { to } \\
\text { CNSb }\end{array}$ & & $\begin{array}{l}\mathrm{F} \\
\mathrm{F} \\
\mathrm{F} \\
\mathrm{F}\end{array}$ & $\begin{array}{ll} & \\
F & \\
F & \text { af } \\
F & \text { af } \\
F\end{array}$ & $\begin{array}{ll}F & \\
C & \\
F & R \\
\text { aff. } & \\
\text { aff. } & \text { ef } \\
\end{array}$ & & & & $\begin{array}{l}\mathrm{C} \\
\mathrm{C} \\
\mathrm{C} \\
\mathrm{C} \\
\mathrm{C} \\
\mathrm{C} \\
\mathrm{C}\end{array}$ & & $\begin{array}{l}\mathrm{C} \\
\mathrm{F} \\
\mathrm{R} \\
\mathrm{R} \\
\\
\mathrm{R}\end{array}$ & $\begin{array}{l}\mathrm{F} \\
\mathrm{F} \\
\mathrm{A} \\
\mathrm{A} \\
\mathrm{A} \\
\mathrm{A} \\
\mathrm{A}\end{array}$ & $\begin{array}{l}\mathrm{C} \\
\mathrm{A} \\
\mathrm{C} \\
\mathrm{C} \\
\mathrm{A} \\
\mathrm{A} \\
\mathrm{C}\end{array}$ & $\begin{array}{l}\mathrm{R} \\
\mathrm{F} \\
\mathrm{F} \\
\mathrm{R} \\
\mathrm{R}\end{array}$ & & & & & & & $\begin{array}{l}\text { cf. } \\
R \\
R\end{array}$ & & & & $\begin{array}{l}\mathrm{R} \\
\mathrm{F} \\
\mathrm{R}\end{array}$ & & & & $\begin{array}{l}\text { ef. } \\
R \\
R \\
R \\
R\end{array}$ & & $\begin{array}{l}\mathrm{F} \\
\mathrm{R} \\
\\
\mathrm{R} \\
\mathrm{R}\end{array}$ & $\begin{array}{l}R \\
R \\
F\end{array}$ & $\begin{array}{l}R \\
R \\
\end{array}$ & $R$ & $\mathrm{~F}$ & & \\
\hline & $\begin{array}{l}17, \mathrm{CC} \\
18, \mathrm{CC} \\
19, \mathrm{CC} \\
\end{array}$ & $\begin{array}{l}\mathrm{P} \\
\mathrm{P} \\
\mathrm{P} \\
\end{array}$ & $\mathrm{CN5a}$ & & & $\begin{array}{l}\mathrm{F} \\
\mathrm{C}\end{array}$ & $\begin{array}{l}\mathrm{F} \\
\mathrm{R} \\
\mathrm{F}\end{array}$ & & & & $\begin{array}{l}\text { C } \\
\text { C } \\
\text { A }\end{array}$ & & $R$ & $\begin{array}{l}\text { C } \\
\text { C } \\
\text { A }\end{array}$ & $\begin{array}{l}\text { A } \\
\text { C } \\
\text { A }\end{array}$ & & & & & & & & & & & & $\mathrm{R}$ & & & & & & $\begin{array}{l}R \\
R \\
R \\
\end{array}$ & R & & & $\begin{array}{l}F \\
F \\
R \\
\end{array}$ & $\begin{array}{l}\mathrm{F} \\
\mathrm{F} \\
\mathrm{R}\end{array}$ & $\mathrm{R}$ \\
\hline & $\begin{array}{l}20, \mathrm{CC} \\
21, \mathrm{CC} \\
22, \mathrm{CC} \\
24, \mathrm{CC} \\
25, \mathrm{CC} \\
26, \mathrm{CC} \\
27, \mathrm{CC} \\
28, \mathrm{CC} \\
29, \mathrm{CC} \\
30, \mathrm{CC} \\
31, \mathrm{CC}\end{array}$ & $\begin{array}{l}\mathrm{P} \\
\mathrm{P} \\
\mathrm{P} \\
\mathrm{P} \\
\mathrm{P} \\
\mathrm{P} \\
\mathrm{P} \\
\mathrm{P} \\
\mathrm{P} \\
\mathrm{P} \\
\mathrm{P}\end{array}$ & $\mathrm{CN}_{4}$ & & & $F$ & aff. & & & & $\begin{array}{l}\text { A } \\
\text { C } \\
\text { C } \\
\text { C } \\
\text { C } \\
\text { C } \\
\text { C } \\
\text { A } \\
\text { C } \\
\text { A } \\
\text { C }\end{array}$ & & & $\begin{array}{l}\text { A } \\
\text { A } \\
\text { C } \\
\text { C } \\
\text { C } \\
\text { F } \\
\text { F } \\
\text { cf. } \\
\text { cf. } \\
\text { C }\end{array}$ & $\begin{array}{l}\text { A } \\
\text { A } \\
\text { C } \\
\text { C } \\
\text { C } \\
\text { C } \\
\text { C } \\
\text { C } \\
\text { C } \\
\text { A } \\
\text { C }\end{array}$ & $\begin{array}{l}F \\
F \\
F \\
F \\
R\end{array}$ & & & & & & & & & & & $\begin{array}{l}R \\
R \\
F\end{array}$ & & & & & & $\begin{array}{l}\text { F } \\
\text { cf. }\end{array}$ & $\begin{array}{l}R \\
R \\
R \\
R \\
R \\
R \\
R \\
R \\
R\end{array}$ & $\begin{array}{l}\mathrm{C} \\
\mathrm{C} \\
\mathrm{R} \\
\mathrm{F} \\
\mathrm{F} \\
\mathrm{F} \\
\mathrm{C}\end{array}$ & $\begin{array}{l}\text { A } \\
\text { A } \\
\text { C } \\
\text { C } \\
\text { A } \\
\text { A } \\
\text { A } \\
\text { C } \\
\text { A } \\
\text { A } \\
\text { A }\end{array}$ & $\begin{array}{l}\mathrm{F} \\
\mathrm{F} \\
\mathrm{F} \\
\mathrm{R} \\
\mathrm{R} \\
\mathrm{F} \\
\mathrm{R} \\
\mathrm{R}\end{array}$ & $R$ & $\begin{array}{l}\mathrm{F} \\
\mathrm{F} \\
\mathrm{R} \\
\mathrm{R} \\
\mathrm{F} \\
\mathrm{C} \\
\mathrm{C} \\
\mathrm{C} \\
\mathrm{A} \\
\mathrm{C}\end{array}$ \\
\hline
\end{tabular}

Note: Symbols as in Table 2. 
Table 7. Occurrence of calcareous nannofossils in core-catcher samples, DSDP Hole 574C, Leg 85.

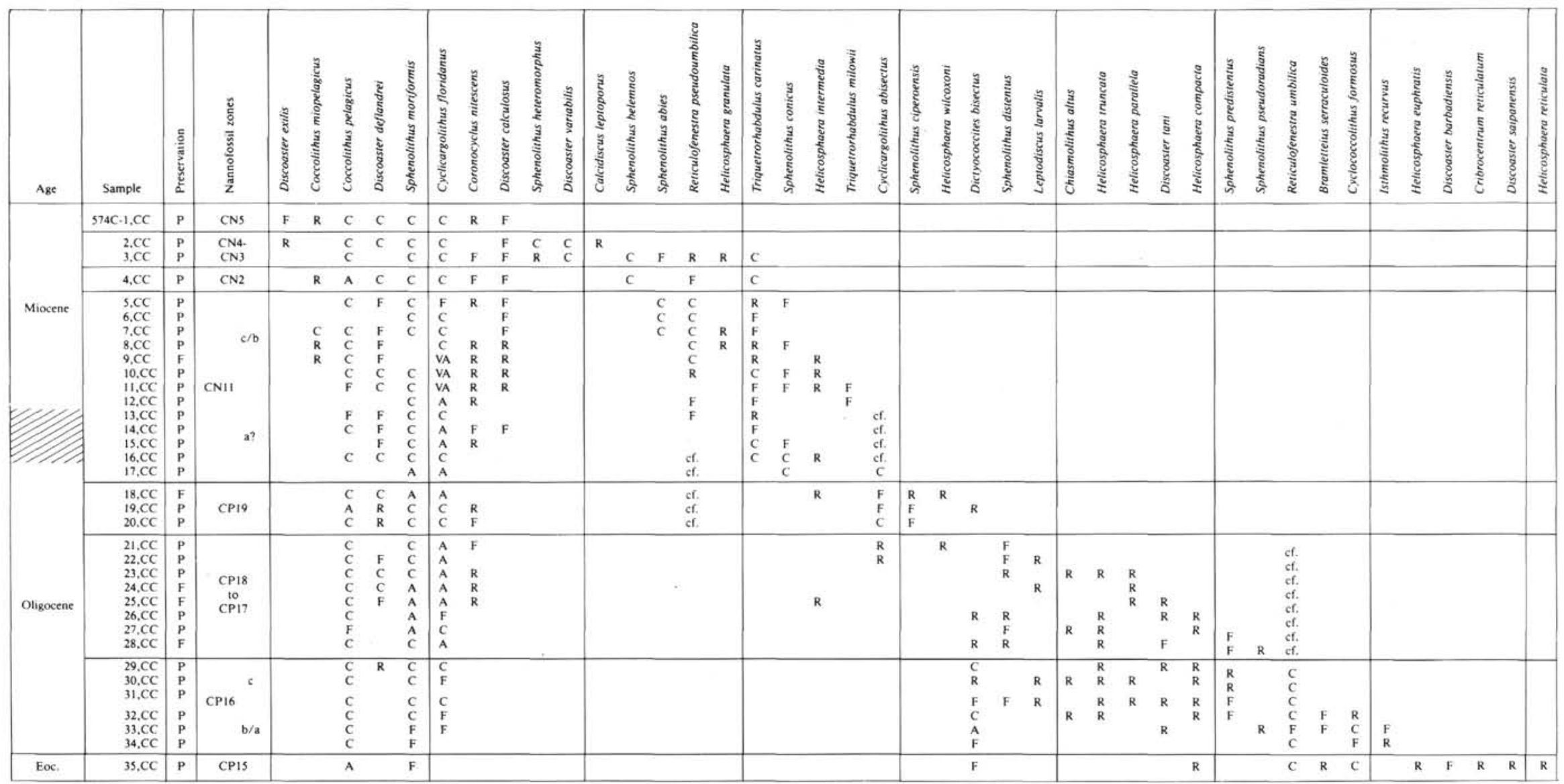

Note: Symbols as in Table 2 . 
Table 8. Occurrence of calcareous nannofossils in core-catcher samples, DSDP Hole 575, Leg 85.

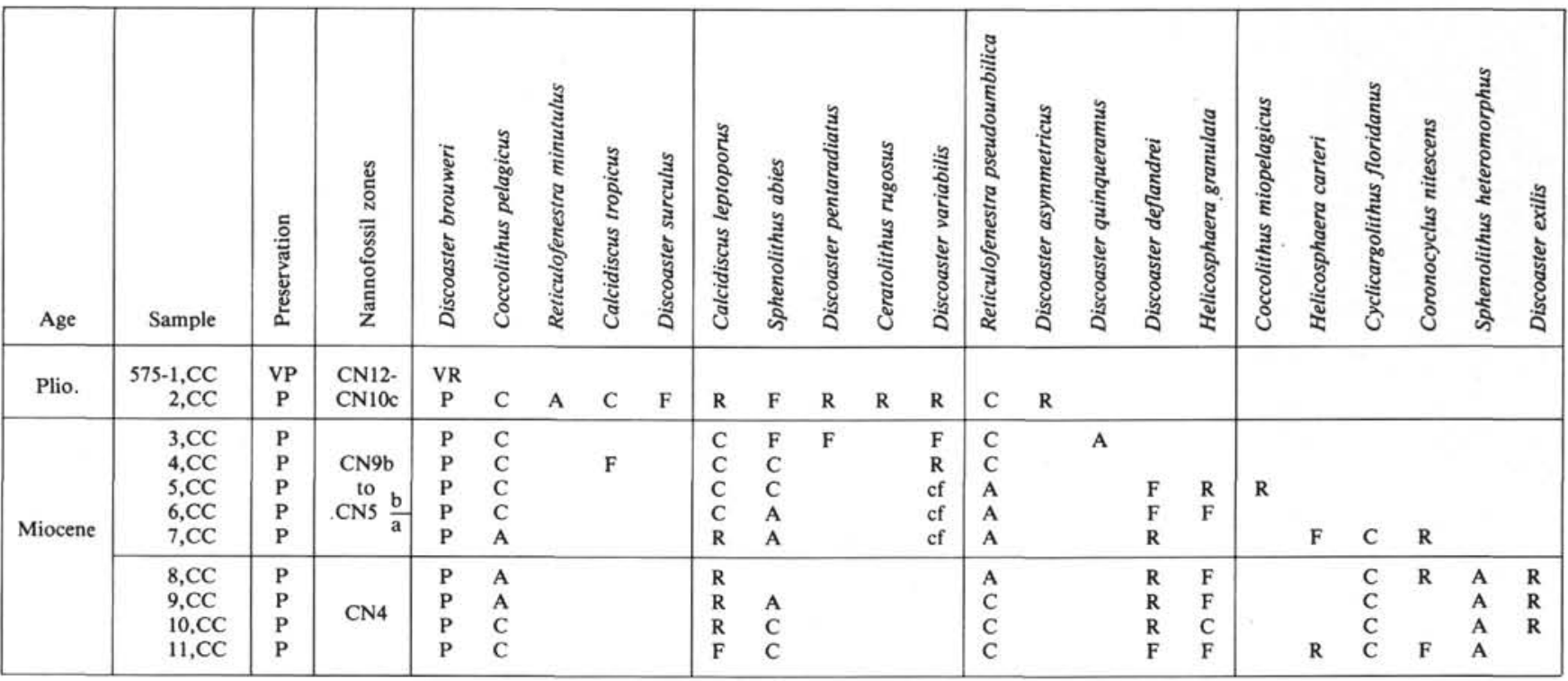

Note: Symbols as in Table 2; $\mathrm{V}=$ very.

Table 9. Occurrence of calcareous nannofossils in core-catcher samples, DSDP Hole 575A, Leg 85.

\begin{tabular}{|c|c|c|c|c|c|c|c|c|c|c|c|c|c|c|c|c|c|c|c|c|c|c|c|c|c|}
\hline Age & Sample & 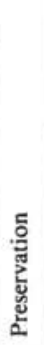 & 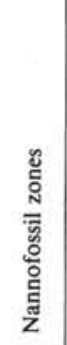 & 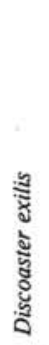 & 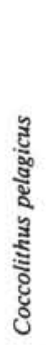 & 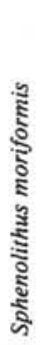 & 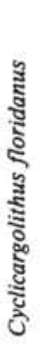 & 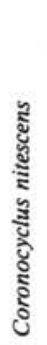 & 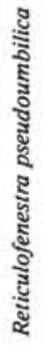 & 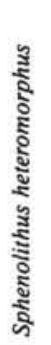 & 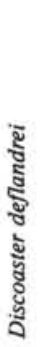 & 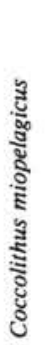 & 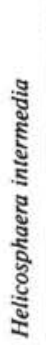 & 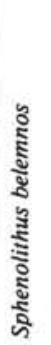 & 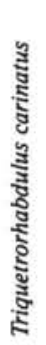 & 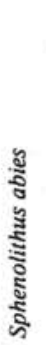 & 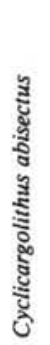 & 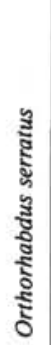 & 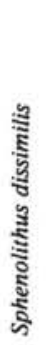 & 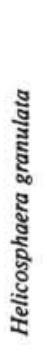 & 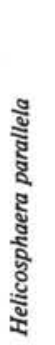 & 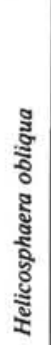 & 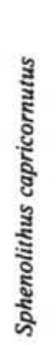 & 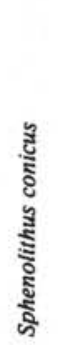 & 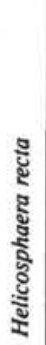 \\
\hline \multirow[b]{3}{*}{ Miocene } & $\begin{array}{r}575 \mathrm{~A}-1, \mathrm{CC} \\
2, \mathrm{CC} \\
3, \mathrm{CC} \\
4, \mathrm{CC} \\
5, \mathrm{CC}\end{array}$ & $\begin{array}{l}\mathrm{P} \\
\mathrm{P} \\
\mathrm{P} \\
\mathrm{P} \\
\mathrm{P}\end{array}$ & $\begin{array}{c}\mathrm{CN} 4 \\
\text { to } \\
\mathrm{CN} 3\end{array}$ & $\begin{array}{l}\mathbf{R} \\
\mathrm{R} \\
\mathrm{R} \\
\mathrm{R}\end{array}$ & $\begin{array}{l}C \\
C \\
C \\
C \\
C\end{array}$ & $\begin{array}{l}\mathrm{C} \\
\mathrm{C} \\
\mathrm{C} \\
\mathrm{C} \\
\mathrm{C}\end{array}$ & $\begin{array}{l}\text { A } \\
\text { A } \\
\text { A } \\
\text { C } \\
\text { C }\end{array}$ & $\begin{array}{l}\text { R } \\
\text { F } \\
\text { F } \\
\text { F } \\
\text { F }\end{array}$ & $\begin{array}{l}\text { C } \\
\text { C } \\
\text { C } \\
\text { C } \\
\text { C }\end{array}$ & $\begin{array}{l}\text { A } \\
\text { A } \\
\text { C } \\
\text { C } \\
\text { C }\end{array}$ & $\begin{array}{l}\mathrm{F} \\
\mathrm{C}\end{array}$ & $\begin{array}{l}\mathrm{R} \\
\mathrm{R}\end{array}$ & $\mathbf{R}$ & & & & & & & & & & & & \\
\hline & $\begin{array}{l}6, \mathrm{CC} \\
7, \mathrm{CC} \\
8, \mathrm{CC} \\
9, \mathrm{CC}\end{array}$ & $\begin{array}{l}\mathrm{P} \\
\mathrm{P} \\
\mathrm{P} \\
\mathrm{P}\end{array}$ & $\mathrm{CN} 2$ & & $\begin{array}{l}C \\
C \\
C \\
C\end{array}$ & $\begin{array}{l}\mathrm{C} \\
\mathrm{C} \\
\mathrm{F}\end{array}$ & $\begin{array}{l}\mathrm{C} \\
\mathrm{F} \\
\mathrm{C} \\
\mathrm{C}\end{array}$ & $\begin{array}{l}F \\
F \\
F \\
F\end{array}$ & $\begin{array}{l}\mathrm{C} \\
\mathrm{C} \\
\mathrm{C} \\
\mathrm{C}\end{array}$ & & $\begin{array}{l}\mathrm{F} \\
\mathrm{R}\end{array}$ & $\mathbf{R}$ & & $\begin{array}{l}\text { F } \\
\text { A } \\
\text { C } \\
\text { F }\end{array}$ & $\mathrm{F}$ & $\begin{array}{l}\mathrm{C} \\
\mathrm{C}\end{array}$ & $\mathbf{R}$ & & & & & & & & \\
\hline & $\begin{array}{l}10, \mathrm{CC} \\
11, \mathrm{CC} \\
12, \mathrm{CC} \\
13, \mathrm{CC} \\
14, \mathrm{CC} \\
15, \mathrm{CC} \\
16, \mathrm{CC} \\
17, \mathrm{CC} \\
18, \mathrm{CC} \\
19, \mathrm{CC} \\
20, \mathrm{CC} \\
21, \mathrm{CC} \\
22, \mathrm{CC} \\
23, \mathrm{CC} \\
24, \mathrm{CC} \\
25, \mathrm{CC} \\
26, \mathrm{CC} \\
27, \mathrm{CC} \\
28, \mathrm{CC} \\
29, \mathrm{CC} \\
30, \mathrm{CC} \\
31, \mathrm{CC} \\
32, \mathrm{CC} \\
33, \mathrm{CC}\end{array}$ & $\begin{array}{l}\mathrm{P} \\
\mathrm{P} \\
\mathrm{P} \\
\mathrm{P} \\
\mathrm{P} \\
\mathrm{P} \\
\mathrm{P} \\
\mathrm{P} \\
\mathrm{P} \\
\mathrm{P} \\
\mathrm{P} \\
\mathrm{P} \\
\mathrm{P} \\
\mathrm{P} \\
\mathrm{P} \\
\mathrm{P} \\
\mathrm{P} \\
\mathrm{P} \\
\mathrm{P} \\
\mathrm{P} \\
\mathrm{P} \\
\mathrm{P} \\
\mathrm{P} \\
\mathrm{P}\end{array}$ & $\mathrm{CN} 1$ & & $\begin{array}{l}\mathrm{C} \\
\mathrm{C} \\
\mathrm{A} \\
\mathrm{C} \\
\mathrm{A} \\
\mathrm{C} \\
\mathrm{C} \\
\mathrm{C} \\
\mathrm{C} \\
\mathrm{C} \\
\mathrm{C} \\
\mathrm{C} \\
\mathrm{A} \\
\mathrm{F} \\
\mathrm{C} \\
\mathrm{F} \\
\mathrm{C} \\
\mathrm{F} \\
\mathrm{F} \\
\mathrm{F} \\
\mathrm{F} \\
\mathrm{C} \\
\mathrm{C} \\
\mathrm{C}\end{array}$ & $\begin{array}{l}\text { C } \\
C \\
C \\
C \\
C \\
C \\
\text { F } \\
\text { C } \\
C \\
C \\
C \\
C \\
\text { C } \\
C \\
C \\
C \\
C \\
\text { R } \\
C \\
C \\
\text { F } \\
C \\
\text { F } \\
\text { C }\end{array}$ & $\begin{array}{l}\text { C } \\
\text { R } \\
\text { C } \\
\text { C } \\
\text { C } \\
\text { C } \\
\text { C } \\
\text { C } \\
\text { C } \\
\text { A } \\
\text { A } \\
\text { A } \\
\text { A } \\
\text { A } \\
\text { A } \\
\text { A } \\
\text { A } \\
\text { A } \\
\text { A } \\
\text { A } \\
\text { A } \\
\text { A } \\
\text { A }\end{array}$ & $\begin{array}{l}F \\
F \\
F \\
F \\
F \\
\\
\\
\\
R \\
R \\
R \\
F \\
R \\
R \\
R \\
R \\
R \\
R \\
R \\
R \\
R \\
R\end{array}$ & $\begin{array}{l}\text { C } \\
\text { A } \\
\text { C } \\
\text { A } \\
\text { C } \\
\text { A } \\
\text { A } \\
\text { A } \\
\text { cf. } \\
\text { cf. } \\
\text { F } \\
\text { C } \\
\text { C } \\
\text { R } \\
\text { F } \\
\text { F } \\
\text { R } \\
\text { R } \\
\text { R } \\
\text { F } \\
\text { F } \\
\text { F }\end{array}$ & & $\begin{array}{l}\text { R } \\
\text { C } \\
\text { F } \\
\text { C } \\
\text { F } \\
\text { C } \\
\text { C } \\
\text { C } \\
\text { F } \\
\text { F } \\
\text { F } \\
\text { A } \\
\text { C } \\
\text { C } \\
\text { C }\end{array}$ & $\begin{array}{l}\text { cf. } \\
\text { C } \\
\text { C } \\
\text { C } \\
\text { C } \\
\text { C } \\
\text { F } \\
\text { C }\end{array}$ & $\begin{array}{l}\mathrm{R} \\
\mathrm{R} \\
\mathrm{R}\end{array}$ & & $\begin{array}{l}\mathrm{R} \\
\mathrm{R} \\
\mathrm{F} \\
\mathrm{C} \\
\mathrm{F} \\
\mathrm{C} \\
\mathrm{F} \\
\mathrm{R} \\
\mathrm{R} \\
\mathrm{F} \\
\mathrm{R} \\
\mathrm{F} \\
\mathrm{F} \\
\mathrm{F} \\
\mathrm{R} \\
\mathrm{R} \\
\mathrm{R} \\
\mathrm{R} \\
\mathrm{F} \\
\mathrm{F}\end{array}$ & $\begin{array}{l}\text { R } \\
\text { R } \\
\text { F } \\
\text { A } \\
\text { A } \\
\text { A } \\
\text { C } \\
\text { C } \\
\text { F } \\
\text { R } \\
\text { C } \\
\\
\text { A } \\
\text { A } \\
\text { A } \\
\text { A } \\
\text { A } \\
\text { F } \\
\text { A } \\
\text { C } \\
\text { C }\end{array}$ & $\begin{array}{l}\text { F } \\
F \\
F \\
\text { F } \\
F \\
F \\
F \\
C \\
F \\
C \\
C \\
C \\
F \\
F \\
C \\
C \\
C \\
C \\
C \\
C \\
C \\
C \\
C \\
C\end{array}$ & $\begin{array}{l}\text { C } \\
\text { F } \\
\text { cf. }\end{array}$ & $\begin{array}{l}\mathrm{F} \\
\mathrm{F} \\
\mathrm{F}\end{array}$ & $\begin{array}{l}\mathbf{R} \\
\mathbf{R} \\
\mathbf{R} \\
\mathbf{R} \\
\mathbf{R} \\
\mathbf{R} \\
\mathbf{R} \\
\mathbf{R}\end{array}$ & $\begin{array}{l}\mathbf{R} \\
\mathbf{R}\end{array}$ & R & $\mathbf{R}$ & $\begin{array}{l}\mathbf{R} \\
\mathbf{R} \\
\mathbf{R}\end{array}$ & $\mathbf{R}$ \\
\hline
\end{tabular}

Note: Symbols as in Table 2. 